REVISTA DE LITERATURA E CULTURA RUSSA

\title{
Исторический процесс в свете христианской антропологии Ф. М. Достоевского
}

\section{Historical process through the prism of F. M. Dostoevsky's Christian anthropology}




\section{Исторический процесс в свете христианской антропологии Ф. М. Достоевского}

\section{Б. H. Tapacoв ${ }^{*}$}

Аннотация: На основе фундаментальных для творческого сознания Достоевского понятий «тайны человека» и христианского реализма, «закона Я» и «закона любви» в статье рассмотрена односторонность биологизаторских и социализаторских концепций человеческой природы с эпохи Просвещения и их связь с энтропийными процессами в духовно-нравственном мире людей и снижающими тенденциями в ходе истории. Показаны, как уходящие из поля зрения рационалистического и прагматического сознания духовные законы жизни трансформируют социальнопрогрессистское проектирование и планирование, вносят в них нигилистические элементы. Подчеркнуто, что методология христианского реализма носит универсальный характер, соединяет «тайну человека» с тайной истории, и становится одним из главных принципов для оценки иерархии ценностей в различных мировоззренческих, идеологических и социальных системах.

\begin{abstract}
Based on the fundamental concepts of the "mystery of man" and Christian realism, the "law of the Ego" and the "law of love" for Dostoevsky's creative consciousness, the article examines the one-sidedness of biologizing and socializing concepts of human nature since the Enlightenment and their connection with entropic processes in the spiritual and moral world of people and declining trends in the course of history. It is shown how the spiritual laws of life, which are leaving the field of view of rationalistic and pragmatic consciousness, transform socialprogressive design and planning, and introduce nihilistic elements into them. It is emphasized that the methodology of Christian realism is universal, that it connects the "mystery of man" with the mystery of history, and becomes one of the main principles for assessing the hierarchy of values in various ideological and social systems.
\end{abstract}

Ключевые слова: Достоевский; «Тайна человека»; Христианский реализм; «Закон Я»; «Закон любви»; Исторический процесс; Апокалиптические признаки

Keywords: Dostoevsky; "Mystery of man"; Christian realism; "Law of the Ego"; "Law of love"; Historical process; Apocalyptic signs 
*Доктор филологических наук, профессор, заведующий кафедрой зарубежной литературы Литературного института имени А.М. Горького, Россия. E-mail: bntarasov@ yandex.ru

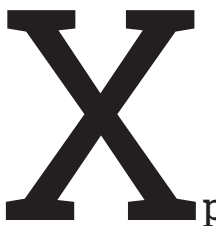

ристианская антропология, аксиология и антропология «реализма в высшем смысле» с его постановкой предельных вопросов и смыслов и стратегической альтернативой развития человека и мира «с Богом» и «без Бога» в творчестве Достоевского пролагает пути для русской религиозной философии, в которой артикулировалась необходимость смены возрожденческо-просветительской парадигмы. Отечественная классическая литература воспринималась многими отечественными мыслителями как своеобразный кладезь тем и проблем и как некий образец подхода к ним. Н. А. Бердяев писал:

Только в XX в. критика по-настоящему оценила великую русскую литературу XIX в., прежде всего Достоевского и Толстого. Духовная проблематика вершин русской литературы была усвоена, ею пропитались, вместе с тем произошло большое изменение, не всегда благоприятное, по сравнению с литературой XIX в. Исчезла необыкновенная правдивость и простота русской литературы. Появились люди двоящихся мыслей. ${ }^{2}$

Это высказывание перекликается с заключением Л. И. Шестова: Русская философская мысль, такая глубокая и своеобразная, получила свое выражение именно в художественной литературе. Никто в России так свободно и властно не думал, как Пушкин, Лермонтов, Гоголь, Достоевский, Толстой и даже Чехов». ${ }^{3}$

Это свободное и властное философическое «думание» в вершинных явлениях русской классической литерату-

\footnotetext{
1 Статья выполнена при поддержке РФФИ. Проект №18-01290043. Аналиэ, интерпретации, понимание как методологические установки в изучении наследия Достоевского.

2 Бердяев, 1997, с. 190.

3 Шестов, 1964, с. 35.
} 
ры обусловлено ее укорененностью в христианской традиции и в родовой памяти православной культуры, что было отмечено С. Л. Франком:

Важным является вопрос, в каких формах культуры и жизни выражена последняя мудрость и в чем, собственно, заключается последний религиозный смысл человеческой жизни и человеческого развития. Именно в русской литературе едва ли можно отделить религиозную философию от исторической, социальной и культурной философии, их необходимо рассматривать вместе. ${ }^{4}$

Вслед за Достоевским Франк сосредотачивается на последних глубинах «тайны человека» и определяет его специфическое отличие от животного и вообще от всего сущего способностью судить и оценивать, дистанцироваться от наличной действительности и смотреть на нее извне, трансцендируя за пределы всего фактически данного (включая и фактическую данность собственного бытия) и соотнося в акте самосознания с более убедительным и первичным авторитетом.

Эта последняя основа, трансцендентное средоточие и верховная инстанция человеческого бытия, как мы знаем - Бог. Поэтому мы вправе сказать, что отношение к Богу, связь с Богом есть определяющий признак самого существа человека. То, что делает человека человеком - начало человечности в человеке - есть его Бого-человечность. ${ }^{5}$

Франк настойчиво подчеркивает роковую двойственность человеческого существования, неизбежно сочетающего в себе имманентное и трансцендентное, духовное и природное, реальную действительность и идеальное бытие. «К существу человека принадлежит сознание его нищеты и нужды, его «misère», как говорил Паскаль; и когда человек это забывает и начинает воображать себя самодержавным творцом и хозяином своей жизни, он строит свою жизнь «на песке», на иллюзии, и горьким опытом убеждается, что впал в гибельное заблуждение.

4 Франк, 1992, с. 494.

5 Франк, 1997, с. 321. 
Но эта его зависимость от Бога и связь с Богом есть вместе с тем его достоинство. [...] Уже самый факт, что человек способен знать эту свою фактическую нищету и скорбеть о ней, есть признак его величия - свидетельство, что его истинное существо не исчерпывается этим отрицательным моментом. Само искание опоры для своего бытия вне себя, само сознание, что такая опора ему нужна и у него есть, обличает, что Бог, в качестве полюса, необходимо противостоящего человеческому бытию, есть тем самым его необходимый коррелят, т. е. что связь с Богом есть внутренний признак самого существа человека. ${ }^{6}$

Франк заостряет (или - или) антитезу между полюсами двуединого существа человека, принадлежащего одновременно к природному и сверхприродному мирам и являющегося как бы местом их встречи и скрещивания. Входя в объективную действительность через свое тело и душевную жизнь (поскольку она определяется телесными процессами и вообще подчиняется естественным закономерностям), человек через свое самобытие (поскольку оно есть реальность для себя сущего и себе самой открывающаяся), через расширение и углубление собственного самосознания входит в состав совсем иного мира и неизбежно соприкасается с альтернативой:

Либо он сознает себя висящим над бездной, то есть обречен впасть в отчаяние и вообще потерять осмысленность своего бытия, либо же ему удается найти безусловную опору для себя в той реальности, которая называется «Бог». Tertium non datur или datur только в страусовой политике закрывания глаз перед объективным составом человеческого бытия. ${ }^{7}$

Аналогичная основополагающая альтернатива вытекает и из творчества П. А. Флоренского. В уже свершившемся историческом опыте он раскрывает онтологический путь распада от Ренессанса к Просвещению и Нигилизму, от «возрождения» к «вырождению».

6 Франк, 1992, с. 313.

7 Франк, 1997, с. 311. 
В методологическую основу для такой стратегической парадигме в русской религиозной философии заложил Достоевский в своей фундаментальной логике о «тайне человека». Эту логику его художественных открытий подчеркнул М. М. Бахтин: «Достоевский сделал дух, то есть последнюю смысловую позицию личности, предметом эстетического созерцания... Он продвинул эстетическое видение вглубь, в новые глубинные пласты, но не вглубь бессознательного, а в глубь-высоту сознания». ${ }^{8}$ Именно сосредоточенность на «последней смысловой позиции» личности и глубинно-высотных пластах сознания, зачастую сокращенных в читательском и исследовательском восприятии, превращает Достоевского в своеобразного мыслителя, рассматривавшего любую жизненную конкретику основополагающих проектов развития мира «с Богом» и «без Бога», в сопряжении главных признаков величия и ничтожества в драматической мистерии человеческого существования. Причем сама методология его мышления, тесно связанная с проникновенным эмпирическим исследованием парадоксов человеческой природы с христианской точки зрения и их неоднозначным преломлением в тех или иных тенденциях, явлениях, поступках, общественном новаторстве, давал ему возможность не только предсказывать трагические катаклизмы XX века с его войнами, революциями и, говоря словами А. И. Герцена, «Чингисханами с телеграфами», но и сегодня служить своеобразным пробным камнем для проверки всяких модных рассудочных утопий и односторонних идеологий.

Способность раскрыть подлинную и объективную иерархию действительно главных и второстепенных для личности проблем и разглядеть сокровенную связь сокрытых движений души и корневых побуждений воли человека с результатами его внешней деятельности, умение распознавать иллюзии относительных ценно-

8 Бахтин, 1986, с. 331. 
стей и социальных условностей, миражи всевозможных репутаций и социальной пропаганды, границы и тупики сциентизма, тонкий яд рационализма и нигилизм здравого смысла позволяют писателю и впредь оставаться авторитетнейшим участником в диалоге идей современного мира и в оценке хода исторического процесса.

Глубинное своеобразие религиозно-философской проблематики и художественной мысли Достоевского еще при его жизни встречало непонимание со стороны читателей и критиков. «Жестокий талант» (Н. К. Михайловский), «больные люди» (П. Н. Ткачев) - подобные определения писателя и его персонажей нередко можно было встретить на журнальных страницах. После кончины Достоевского наметилось стремление к адекватному и систематическому изложению основ его мировоззрения и творчества в трудах крупных русских мыслителей (В. С. Соловьев, В.В.Розанов, Д. С. Мережковский, С. Н. Булгаков, С. Л. Франк, Вяч. И. Иванов, Н. А. Бердяев, Л. И. Шестов и др.), для многих из которых постижение его творчества стало важной вехой на пути «от марксизма к идеализму», создавая методологическую основу для собственных построений, и вместе с тем порою подвергалось субъективным интерпретациям, подчиняясь теоретическим установкам «нового религиозного сознания» (Н. А. Бердяев), «третьего завета» (Д. С. Мережковский), «второго измерения мышления» (Л. Н. Шестов) и Т. П.

Важную роль понимании значительности и масштаба творчества писателя сыграла книга М.M. Бахтина «Проблемы поэтики Достоевского», диалогическая концепция которой была скорректирована признанием им самим основополагающего значения христианской модели мира и человека в художественном мышлении автора «Братьев Карамазовых». Сам Бахтин откровенно говорил, что в своей книге оторвал форму от главных философских вопросов и «прямо не мог говорить о том, 
чем мучился Достоевский всю жизнь - существованием Божиим. Мне ведь приходилось вилять - туда и обратно. Приходилось за руку себя держать. Даже церковь оговаривал». ${ }^{9}$

Достоевского изначально впечатляла неискоренимая мерцательная двойственность («текучесть» по Л. Толстому) человеческой природы, соединяющей в себе, если воспользоваться известными строками Г. Р. Державина («я царь, я раб, я червь, я бог») царские и рабские, божественные и природные начала. Опять-таки еще в юности он отметил неизбывное срастание элементов величия и ничтожества человеческого существования, когда во всегда двоящихся картинах мира добро и зло многообразными переплетениями событий и поступков слиты в тесный неразрубаемый узел.

Атмосфера души человека состоит из слияния неба с землею, какое противузаконное дитя человек: закон духовной природы нарушен, мне кажется, что мир наш - чистилище духов небесных, отуманенных грешною мыслию. Мне кажется, что мир принял значение отрицательное, и из высокой изящной духовности вышла сатира. ${ }^{10}$

С точки зрения Достоевского, эту фундаментальную двойственность и противозаконность можно характеризовать и как потенциальную переходность: «Мы, очевидно, существа переходные... люди становятся бесами или ангелами». ${ }^{11}$ По его убеждению, предотвращение падения вниз «к бесам» и движение вверх «к ангелам» невозможно без полного и глубокого сознания этой двойственности и противозаконности и радикального преображения рабской заносчивости в лоне «темной основы нашей природы», что особо подчеркнул в статье о нем Вл. Соловьев:

\footnotetext{
9 Цит. по: Бочаров, 1993, с. 71-72.

10 Достоевский, 1985, с. 50.

11 Достоевский, 1974а, с. 184.
} 
Пока темная основа нашей природы, злая в своем исключительном эгоизме и безумная в своем стремлении осуществить этот эгоизм, все отнести к себе и все определить собою, - пока эта темная основа у нас налицо - не обращена - и этот первородный грех не сокрушен, до тех пор невозможно для нас никакое настоящее дело и вопрос что делать не имеет разумного смысла. Представьте себе толпу людей, слепых, глухих, увечных, бесноватых, и вдруг из этой толпы раздается вопрос: что делать? Единственный разумный здесь ответ: ищите исцеления; пока вы не исцелитесь, для вас нет дела, а пока вы выдаете себя за здоровых, для вас нет исцеления [...] Истинное дело возможно, только если и в человеке и в природе есть положительные и свободные силы света и добра; но без Бога ни человек, ни природа таких сил не имеют. ${ }^{12}$

В высшей логике Достоевского никакие научные теории, революции, общественные преобразования, добрые намерения или благие пожелания не способны исцелить человека от «противузаконности», если не преображена и исцелена темная основа нашей природы, а ее «рабские» силы исключительного эгоизма одолевают «положительные силы добра и света», присваивают и перерабатывают на свой лад любые гуманистические начинания. Потому-то вопрос «что делать?», задававшийся не только Чернышевским, Л. Н. Толстым или Лениным получал в реальной действительности тупиковые разрешения, что вопрошатели не учитывали ведущих сил не преображенной «темной основы нашей природы».

Вместо того, чтобы распутывать «клубок» изначальной двусоставности бытия, вызванной первородным грехом, исследовать и преодолевать «незавершенность» (Гр. Нисский), «недосиженность» и «недоделанность» человека, научная и социальная мысль с эпохи Возрождения и Просвещения капитулировала перед этими проблемами, удалила их из центра на периферию сознания, отказалась от осмысления бесовско-ангельских следствий в коренной двойственности человеческой

12 Соловьев, 1988 , с. 311. 
природы, от оценки влияния червиво-рабских ее начал (гордыни, тщеславия, властолюбия, сластолюбия, сребролюбия, чревоугодия, озлобленности и т. п.) над царско-божескими (свобода, любовь, совесть, милосердие, справедливость, честь, достоинство, самопожертвование и т. п.), как бы отрывая человека от Бога, поместив его в однородный тип натуралистического бытия и одновременно (но нелогично и безосновательно) «по-горьковски» провозгласив, что «человек - это звучит гордо».

Для понимания обозначенной онтологической проблематики, концов и начал Желания и Свободы в представлении Достоевского, их самораскрытия и перехода вверх или вниз, к ангелам или бесам, чрезвычайно важна запись, сделанная им непосредственно после кончины первой жены.

Возлюбить человека, как самого себя, по заповеди Христовой, - невозможно. Закон личности на земле связывает. Я препятствует. Один Христос мог, но Христос был вековечный от века идеал, к которому стремится и по закону природы должен стремиться человек. Между тем после появления Христа, как идеала человека во плоти, стало ясно как день, что высочайшее, последнее развитие личности именно и должно дойти до того (в самом конце развития, в самом пункте достижения цели), чтоб человек нашел, сознал и всей силой своей природы убедился, что высочайшее употребление, которое может сделать человек из своей личности, из полноты развития своего Я, - это как бы уничтожить это Я, отдать его целиком всем и каждому безраздельно и беззаветно. И это величайшее счастие. Таким образом, закон я сливается с законом гуманизма [...] человек есть на земле существо только развивающееся, следовательно, не оконченное, а переходное [...]. . $^{13}$

Итак, человек стремится на земле к идеалу, противуположному его натуре. Когда человек не исполнил закона стремления к идеалу, то есть не приносил любовью в жертву своего я людям или другому существу (я и Маша), он чувствует страдание и назвал это состояние грехом. ${ }^{14}$

13 Достоевский, 1980, с. 112-113.

14 Достоевский, 1980, с. 117. 
Углубленное исследование самих корней подобных фундаментальных парадоксов, приобретающих на поверхности душевной жизни отдельной личности и общественных отношений в целом различные выражения, становится главной писательской задачей Достоевского. Его художественно-философскую методологию «христианского реализма» можно характеризовать как пневматологию, в которой истинное значение психологических, политических, идеологических, экономических, эстетических и иных проблем раскрывается в сопоставлении с тем или иным основополагающим образом человека, с его коренными представлениями о своей природе, о подлинной сущности, об истоках, цели и смысле бытия. Сам писатель называл ее «реализмом в высшем смысле»: «меня зовут психологом: неправда, я лишь реалист в высшем смысле, то есть изображаю все глубины души человеческой». ${ }^{15}$ И еще одно самоопределение:

При полном реализме найти человека в человеке. Это русская черта по преимуществу, и в этом смысле, я конечно, народен (ибо направление мое истекает из глубины христианского духа народного), - хотя и неизвестен русскому народу теперешнему, но буду известен будущему. ${ }^{16}$

Формула «найти человека в человеке» включает в себя, по крайней мере, три взаимосвязанных аспекта. Во-первых, это сердечно-волевое ядро личности, в котором зарождаются доминантные качества ее желания и свободы, предопределяющие ее движение к закону «я» или «закону любви». Во-вторых, найти человека в человеке значит разглядеть в его падшести «лик человеческий». Наконец, в-третьих, это «угадывание» фазиса его будущего состояния, ибо человек не «исчерпывается одним настоящим» на основе проникновения в борения его доброй и злой воли, господства «царской» или «рабской» доминанты в его двусоставной духовной природе.

15 Достоевский, 1984, с. 65.

16 Достоевский, 1984, с. 65. 
Углубленное, укрупненное и заостренное исследование самых корней в подобной сокрытой фундаментальной динамике, приобретающей на поверхности душевной жизни личности (в психологии) и общественной жизни в целом, в характерах и действиях его персонажей самые разные и нередко парадоксальные выражения, становится принципиальной писательской задачей Достоевского, в основе которой и лежит мучивший его вопрос «существования Божия» и «последней смысловой позиции».

По Достоевскому, в глубинно-высотных пластах человеческого духа спит, дремлет или бодрствует самый главный вопрос "кто есть человек - продукт стихийной игры слепых сил природы, «свинья естественная», как утверждает, например, Ракитин в «Братьях Карамазовых» и подобные ему персонажи в других романах, или образ и подобие Божие? Если человек со всеми своими духовными устремлениями и нравственными страданиями принимает себя, опираясь на материалистическую гипотезу, лишь за мышь, пусть и «усиленно сознающую мышь» (так выражается герой «Записок из подполья»), тогда нелогично надеяться на какое-то братство и любовь среди людей. (Человек произошел от обезьяны, следовательно, люди должны любить друг друга - так вслед за Достоевским иронизировал Вл. Соловьев над абсурдным силлогизмом, неправомерно сочетавшим моральный редукционизм материалистического мировоззрения с эвдемоническим человеколюбием.)

И, напротив, если человек воспринимает себя как образ и подобие Божие, тогда он удовлетворяет глубинную, более или менее осознанную потребность в не теряемом со смертью смысле своего существования, а все специфически человеческие свойства, слитые с действенной памятью о Первообразе и его заповедях, становятся, по Достоевскому, не внешней условностью, а внутренней силой, способной преодолевать природный плен биологического отбора, превозмогать иго натуральных страстей, гедонистических склонностей, властных притя- 
заний, господствующей конъюнктуры, своекорыстных расчетов, словом, тех «рабских» свойств, которые в разной степени, форме и пропорции господствуют в миропредставлении и жизненной ориентации «усиленно сознающей мыши» и вносят катастрофические элементы энтропии, дисгармонии и разлада во взаимоотношения людей. По его неизменному убеждению, от смутно ощущаемого или явно сознаваемого ответа на главный вопрос о собственной сущности, с разной степенью отчетливости и вменяемости дающий о себе знать, зависит вольное или невольное предпочтение определенных ценностей, направление воли и желаний, та психологическая доминанта, которая в конечном итоге предустанавливает и активизирует идейный выбор или конкретный рисунок жизни, судьбу отдельной личности, целого народа, всего человечества.

«Роковой и вековечный вопрос о необходимости понятия бессмертия души для прогресса», - заключает писатель в результате раздумий о «тайне человека», как бы соединяя проблемы религии и высокой метафизики с ходом эмпирической истории и конкретной деятельностью людей. Он заключает в одном из писем:

Представьте себе, что нет Бога и бессмертия души (бессмертие души и Бог - это все одно, одна и та же идея). Скажите, для чего мне надо жить хорошо, делать добро, если я умру на земле совсем? Без бессмертия-то все дело в том, чтоб достигнуть мой срок, и там все хоть гори. А если так, то почему мне (если я только надеюсь на мою ловкость и ум, чтоб не попасться закону) и не зарезать другого, не ограбить, не обворовать или почему мне если уж не резать, так прямо не жить за счет других, в одну свою утробу?..7

Достоевский неоднократно утверждает, что «высшая идея на земле лишь одна» и все остальные, занимающие ум и сердце человека «высшие идеи жизни... лишь из нее одной вытекают». Более того, вера в бессмертие души есть «единственный источник живой жизни на земле

17 Достоевский, 1988а, с. 10. 
- жизни, здоровья, здоровых идей и здоровых выводов и заключений», ибо только в этом единственном случае человек постигает всю разумную цель свою на земле, а надежда на вечную жизнь еще крепче и дружественнее связывает его с землей и другими людьми.

Таким образом, если человек есть образ и подобие Божие, если душа бессмертна, а его жизнь освещается абсолютным идеалом, тогда человек удовлетворяет свою глубинную потребность («последнюю смысловую позицию») в не теряемом со смертью смысле своего существования, обретает свободу от «закона Я», ту полноту сознания, успокоенность сердца и направленность воли, то психическое здоровье, которое позволяет ему выйти из-под ига ненасытных устремлений и мучительных колебаний «темной основы нашей природы», соразмерно-пропорционально относиться к земным делам, не преувеличивать ближайшие жизненные цели и не превращать их в источник явного или неявного соперничества с другими людьми, а использовать для согласия и любви. Только в этом случае, не перестает подчеркивать Достоевский, человек стремится к освобождению от «рабских» свойств «закона Я», к преображению и исключению из оснований своей деятельности (разумеется, в разной степени и с неодинаковым успехом) разрушительного фермента корыстолюбивых побуждений и капитальных страстей. Благодаря чему, собственно говоря, еще сохраняются люди, не участвующие в соперничестве самолюбий, властолюбий и сластолюбий в «шуме» и «ярости» разнообразных и сменяющихся форм общественного процесса и как бы удерживающие текущую действительность от окончательного падения.

Если же душа смертна, тогда, полагает Достоевский, происходит самая главная и роковая подмена, когда место абсолютного идеала как гаранта Цели и Смысла занимают суррогаты и идолы. По его убеждению, одна из основных тайн человеческой природы заключается в преклонении перед авторитетом - если не перед Богом, то перед идолом. Или - или, третьего не дано. «Невозмож- 
но и быть человеку, чтобы не преклониться, не снесет себя такой человек, да и никакой человек, - выражает мысль автора Макар Иванович Долгорукий в «Подростке», - и Бога отвергнет, так идолу поклонится - деревянному, али златому, аль мысленному». ${ }^{18}$ Например, Алексей Карамазов если бы «порешил, что Бога и бессмертия нет, то сейчас бы и пошел в атеисты и социалисты», т. е. подчинился бы одной из тех обманчивых и суррогатных вер во временные и относительные ценности, которые управляют поведением людей в границах «темной основы нашей природы» - будь то вера в науку, деньги, свои собственные силы, государство, нацию, гражданское общество, цивилизацию, прогресс, самозарождающуюся Вселенную, инопланетян, в построение очередной Вавилонской башни, социального муравейника, превращающегося в курятник, хрустального дворца, оборачивающегося «парикмахерским развитием».

В историческом процессе вообще и на каждом его этапе в частности Достоевский обнаруживает тот же самый фундаментальный парадокс, что и в душе отдельного человека: сознательное, бессознательное, или даже воинственное, насильственное забвение идеального измерения бытия и божественного происхождения человека при одновременно автоматически необходимой опоре на так называемые «реалистические» основания, здравый смысл или разумный эгоизм, экономическую выгоду или утилитарную мораль умаляют высшие смысловые связи людей и предполагают снижающие, вульгаризирующие модификации их проектов. По Достоевскому, забвение своей «высшей половины», образа Божия есть болезнь (люди больны своим здоровьем, то есть утилитарной рассудочностью, иррационально оборачивающейся духовными и историческими провалами), без лечения которой в конце концов неизбежно торжествует «скотство» и «языческие фантазии». В логике писателя любой «естественный», изобретенный эманси-

18 Достоевский, 1975, с. 302 
пированным разумом идеал всегда оказывается поверхностным и грубым, не только не просветляет «темную основу нашей природы», но зачастую маскирует, утончает и усиливает ее разрушительные свойства, а потому попытки его реализации не только не прерывают, а нередко и разветвляют цепочки господствующего в мире зла и безумия.

В конечном итоге именно духовное начало играет в истории первостепенную роль, предопределяя направление, содержание и характер творческой, художественной или научной деятельности, цели и задачи использования тех или иных «внешних» достижений. Следовательно, «восходящее» или «нисходящее» развитие истории зависит не столько от изобретаемых общечеловеческих ценностей (при уже существующих христианских!) или изменяющихся социальных учреждений, научных открытий или промышленных революций, сколько от "внутренних» установок сознания, своеобразия нравственных принципов и мотивов поведения, влияющих по ходу жизни на рост высших «царских» свойств личности или, напротив, на их угасание.

Опыт, однако, показывал Достоевскому, что коноводы разворачивающихся в его время капиталистических и социалистических проектов, уповающие на разум или науку, здравый смысл или прагматизм, склонны были игнорировать этот вопрос, не замечать его значения для сохранения не только их же собственных гуманистических «идеалов», но и вообще жизни на земле. Для Достоевского же «роковой и вековечный вопрос» стал самым главным и решающим. В письме Н. А. Любимову, говоря не только о социалистах, но и о всяких иных реформаторах, строителях всевозможных модификаций Вавилонской башни, опирающихся (по логике великого инквизитора) на «низкое происхождение» человека, на «раба», а не «царя» в нем, не на исцеление его духовной немощи и соответственно принижение всего высшего, «низведение человека до стадного скота», он подчеркивал: 
Вопрос ставится у стены: “Презираете вы человечество или уважаете, вы, будущие его спасители?” И все это будто бы у них во имя любви к человечеству: "Тяжел, дескать, закон Христов и отвлеченен, для слабых людей невыносим" - и вместо закона свободы и Просвещения несут им закон цепей и порабощения хлебом..$^{19}$

Именно в свете христианской антропологии Достоевский оценивает текущие исторические процессы своего времени, а также их ближайшие и дальние перспективы. Генеалогию этих процессов он возводил к Великой французской революции, когда произошло не обновление общества на провозглашенных идеалах, как ожидалось, а лишь «победа одного могучего класса над другим», когда «обновился лишь деспотизм» с негласным девизом:

Убирайся прочь, а я займу твое место». Оказалось, что «новые победители мира (буржуа) еще, может быть, хуже прежних деспотов (дворян) и что "свобода, равенство и братство" оказались лишь громкими фразами и не более. Мало того, явились и такие учения, по которым из громких фраз они оказались еще и невозможными фразами. Победители произносили или, лучше, припоминали эти три сакраментальные слова уже насмешливо...20

Насмешливость риторического припоминания заключалась в том, что не изменялась, а в лицемерных формах прорывалась, смешивая, вместо разделения, добро и зло, «темная основа нашей природы», еще более внутренне укреплялись принципы «закона Я».

O, конечно, человек всегда и во все времена боготворил материализм и склонен был понимать свободу лишь в обеспечении себя накопленными изо всех сил и запасенными всеми средствами, деньгами. Но никогда эти стремления не возводили так откровенно и так поучительно в высший принцип, как в нашем девятнадцатом веке. "Всяк за себя и только за себя" вот нравственный принцип большинства теперешних людей, основная идея буржуазии, заменившей собою

19 Достоевский, 1988b, с. 68.

20 Достоевский, 1981a, с. 34. 
в конце прошлого столетия прежний мировой строй и ставшая главной идеей всего нынешнего столетия во всем европейском мире, и даже не дурных людей, а, напротив, трудящихся, не убивающих, не ворующих. А безжалостность к низшим классам, а падение братства, а эксплуатация богатого бедным, - о, конечно, все это было и прежде и всегда, но не возводилось же на степень высшей правды и науки, но осуждалось же христианством, а теперь, напротив, возводится в добродетель... Наступает, напротив, материализм, слепая, плотоядная жажда личного обогащения, жажда личного накопления денег всеми средствами, - вот все, что признано за высшую цель, за разумное, за свободу вместо христианской идеи спасения лишь посредством теснейшего и братского единения людей. ${ }^{21}$

Для реализации потребностей гордыни, тщеславия, господства, власти, наслаждения и других ведущих сил в «законе Я» в ходе европейских революций формировалась своеобразная и благоприятная общественно-экономическая атмосфера, о которой писал Маркс в «Немецкой идеологии»:

Представляется совершенно нелепым сведение всех многообразных человеческих взаимоотношений к единственному отношению полезности - эта по видимости метафизическая абстракция проистекает из того, что в современном буржуазном обществе все отношения практически подчинены только одному абстрактному денежно-торгашескому отношению [...] у Гольбаха вся деятельность индивидов в их взаимном общении, например речь, любовь и т. д., изображается в виде отношений полезности и использования. Таким образом, действительные отношения, из которых он исходит, - это речь, любовь, определенные действенные проявления определенных свойств индивидов. Но эти отношения не обладают здесь свойственным им специфическим значением, а служат выражением и проявлением некоего третьего, подставленного вместо них, отношения, именно отношения полезности или использования. ${ }^{22}$

21 Достоевский, 1983, с. 84-85.

22 Маркс, Энгельс, 1955, с. 409-410. 
Сведение специфических значений нравственных понятий к отношению полезности или использования при господстве денежно-торгашеского абсолюта, по Достоевскому, лишает их самостоятельной и активной роли, что способно вести к угасанию высших свойств личности. «Господин Лебезятников, - говорит в «Преступлении и наказании» Мармеладов Раскольникову, - следящий за новыми мыслями, объяснял намедни, что сострадание в наше время даже наукой воспрещено и что так уже делается в Англии, где политическая экономия»²3. Сам же Лебезятников заявляет: «"Благороднее”, “великодушнее” - все это вздор, нелепости, старые предрассудочные слова, которые я отрицаю!» ${ }^{24}$. К предрассудочным словам относит племянник Лебедева совесть и честь, заменяя их более точным и реальным, с его точки зрения, понятием здравого смысла. Своеобразную апологию отношению полезности или использования в «Преступлении и наказании» произносит Лужин:

Наука же говорит: возлюби, прежде всех, одного себя, ибо все на свете на личном интересе основано. Возлюбишь одного себя, то и дела свои обделаешь как следует, и кафтан твой останется цел. Экономическая же правда прибавляет, что чем более в обществе устроенных частных дел и, так сказать, целых кафтанов, тем более для него твердых оснований и тем более устраивается в нем и общее дело. Стало быть, приобретая единственно и исключительно себе, я именно тем самым приобретаю как бы и всем и веду к тому, чтобы ближний получил несколько более рваного кафтана и уже не от частных, единичных щедрот, а вследствие всеобщего преуспеяния. Мысль простая, но, к несчастию, слишком долго не приходившая, заслоненная восторженностью и мечтательностью, а казалось бы, немного надо остроумия, чтобы догадаться... ${ }^{25}$

На двусмысленность движения к совокупному преуспеванию через самолюбие и корысть указывает Лу-

23 Достоевский, 1973а, с. 14.

24 Достоевский, 1973а, с. 285.

25 Достоевский, 1973а, с. 116. 
жину Разумихин, подчеркивающий, что «общее дело» постоянно пакостится скрытым соперничеством и неуемной жадностью его участников, искажением в свой интерес. Предел же этого искажения объясняет Лужину Раскольников: «А доведите до последствий, что вы давеча проповедовали, и выйдет, что людей можно резать...». ${ }^{26}$ Обусловленное «законом Я» искажение в свой интерес создавало контраст между материальными достижениями капитализирующего общества и упадком нравственного настроя, понижением духовного уровня личности в нем, усыплением ее божественно-царских свойств. Главный герой романа «Подросток» сокрушается: «нравственных идей теперь совсем нет; вдруг ни одной не оказалось, и, главное, с таким видом, что как будто их никогда и не было...»..27 В девятнадцатом веке, заключает Достоевский, «все действительно хотят счастья [...]. Общество не хочет бога, потому что бог противоречит науке». ${ }^{28}$ Однако «счастье» в лоне не просветленной, а по-своему замаскированной и припудренной, модернизированной «темной основы нашей природы» при господстве «пятой стихии» имеет свою логику развития, которая приводит к отчуждению человека от его достоинств и от других пюдей. Отчуждение, по представлению Маркса, помимо прочего, «проявляется в том, что каждая вещь оказывается иной, чем она сама, что деятельность оказывается чем-то иным и что, наконец, надо всем вообще господствует нечеловеческая сила». ${ }^{29}$ Инаковость, то есть несоразмерность восприятия вещей и событий, людей и идей в их подлинной иерархии и ценности, и отмеченная ранее перевернутость сознания, обесценивающая специфическое содержание божественно-царских свойств личности и возвышающая червиво-рабские, и есть проявление дьявольской

\footnotetext{
26 Достоевский, 1973а, с. 118.

27 Достоевский, 1975, с. 54.

28 Достоевский, 1982, с. 160.

29 Маркс, Энгельс, 1956, с. 608.
} 
силы отчуждения и овеществления человеческих отношений. По заключению М. М. Бахтина, Достоевский с огромной проницательностью сумел увидеть проникновение этого отчуждающего и овеществляющего обесценивания человека во все поры современной ему жизни и «в самые основы человеческого мышления», в чем и состоял его глубинный смысл борьбы за человеческую душу.

Для осуществления новой жизненной стратегии не нужны, более того, мешают и становятся антисистемными «великодушными порывами», любовь, совесть, справедливость, милосердие, сострадание, честь, честность, достоинство и другие божественно-царские свойства личности, поскольку они находятся вне сферы торгашеско-денежных отношений и мешают их эффективной реализации, теряют свое специфическое значение и содержание, свою сущность и превращаются в свою противоположность.

Отмеченные выше антропологические особенности функционирования денег по-своему претворены и в романе «Подросток», где автор показывает разложение родовых, семейных и общественных связей в капитализирующейся России. Предметом художественного анализа становится неготовность или, как часто выражался Достоевский, «недоделанность» целомудренной в своей основе, но уже испорченной общей жизненной атмосферой и господством денежно-торгашеского абсолюта души, ищущего справедливости на неправедных путях, в поле действующих сил, говоря словами Вл. Соловьева, «исключительного эгоизма», и становится предметом художественного анализа писателя. В образе Аркадия Долгорукого рельефно воплощена пульсация «темной основы нашей природы», в границах которой направленность воли, особенности характера и своеобразие навязчивой «идеи» соотносятся друг с другом в неразрывном целостном единстве. В подготовительных материалах к произведению автор подчеркивал: 
ОЧЕНЬ ВАЖНОЕ. Подросток во весь роман не покидает своей идеи о Ротшильде окончательно. Эта idea fixa есть выход изо всего, из всех вопросов и затруднений. Она основана на чувстве гордости, формулировавшейся в идее уединения [...] Во всем романе вести так, чтобы придать этой идее значение в романе главнейшее. ${ }^{30}$

Затруднения, униженность и оскорбленность юноши обострили в нем эгоистическую гордыню, которая сызмальства впитывалась в его переживания: «...с самых первых мечтаний моих, то есть чуть ли не с самого детства, я иначе не мог вообразить себя как на первом месте, всегда и во всех оборотах жизни». ${ }^{31}$ Когда же воображаемое не совпадает с действительностью, уязвленное самолюбие заставляет Подростка отъединиться от тех, кто как-либо превосходит его. Он вообще не любит людей, общение с которыми становится для него тяжелым занятием чуть ли не с двенадцатилетнего возраста и от которых он все больше замыкается «в свою скорлупу», как черепаха, уходит в свой угол, погружается в свою идею: «Нет, мне нельзя жить с людьми [...] Моя идея угол». ${ }^{32} \mathrm{Ho,} \mathrm{живя} \mathrm{в} \mathrm{«скорлупе»,} \mathrm{в} \mathrm{«углу»,} \mathrm{в} \mathrm{«идее»,} \mathrm{Аркадий}$ Долгорукий не может полностью отъединиться от людей, поскольку он связан с ними своей эгоистической гордыней, стремлением к первенству и господству над ними. В условиях новых общественных отношений наиболее подходящим средством для одновременного отчуждения, возвышения и господства служили деньги. Богатство, отмечал Достоевский в записной книжке, создавало условия для механического усиления личности и ее отъединения от целого. Поэтому именно богатые люди, особенно процветавшие в Америке, пленили воображение Подростка, когда он мечтал по ночам об отъединенном от людей могуществе над ними: «К себе, к себе! Все порвать и уйти к себе! [...] В Америку! К себе, к

\footnotetext{
30 Достоевский, 1976, с. 105-106.

31 Достоевский, 1975, с. 73.

32 Достоевский, 1975, с. 48.
} 
одному себе! Вот в чем вся "моя идея" ». ${ }^{33}$ Свойственное «темной основе нашей природы» и выражающееся в разных формах эгоцентрического сознания «к себе», механически восполняющего и умножающего индивидуальные сущностные силы, ассоциируется в уме Подростка с фигурой Ротшильда, ибо, став подобным ему, думает он, «я уже тем самым разом выхожу из общества». ${ }^{34} \mathrm{OH}$ считал, что такой выход из общества может позволить ему взять верховную власть и признается, что жаждал могущества всю свою жизнь (эта жажда, как известно, снедала и бальзаковского Гобсека). Пример ничем не ограниченного своеволия, тайной «механической» силы, способной через денежное могущество править миром, Аркадий Долгорукий находит в образе «пушкинского скупого рыцаря», который напоминает Гобсека, готового купить все на свете. «Скупой рыцарь» и сравнивает себя с демоном, которому «все послушно», он же - ничему. Тайное мечтание непослушного демона, злато которого впитало в себя кровь и слезы людей, находит высшее наслаждение в том, что он может принудить, поработить и использовать противоположное его духу - добродетель, вольный гений музы и т. п. Сердечные грезы настраивают Подростка на аналогичное наслаждение:

Мне нравилось ужасно представлять себе существо, именно бесталанное и серединное, стоящее перед миром и говорящее ему с улыбкой: вы Галилеи и Коперники, Карлы Великие и Наполеоны, вы Пушкины и Шекспиры, вы фельдмаршалы и гофмаршалы, и вот я - бездарность и незаконность, и все-таки выше вас, потому что вы сами этому подчинились. ${ }^{35}$

Следует заметить, что ротшильдовская идея на первый взгляд неожиданно, но, по сути, закономерно, несмотря на разницу содержания, перекликается с шигалевской идеей в «Бесах», поскольку обе не только игнорируют божественно-царские свойства личности,

33 Достоевский, 1975, с. 60.

34 Достоевский, 1975, с. 66.

35 Достоевский, 1975, с. 76-77. 
но и подчиняют их рабско-червивым, находя опору и поддержку в «темной основе нашей природы». Петр Верховенский так характеризует шигалевскую идею, в реализации которой предполагалось всякого гения погасить еще в младенчестве, привести всех к «одному знаменателю» и полному «равенству» (как это делают на свой лад деньги): «Шигалев гениальный человек! [...] У него хорошо в тетради [...] Цицерону отрезывается язык, Копернику выкалываются глаза, Шекспир побивается каменьями - вот шигалевщина!..». ${ }^{36}$ Примечательно, что в обоих случаях, несмотря на разницу в «капиталистической» И «социалистической» логике, наблюдается своеобразная «игра на понижение», обеспечивающая завистливое устремление тех, кто был «ничем», стать «всем». «В том-то и “идея" моя, в том-то и сила ее, что деньги - это единственный путь, который приводит на первое место даже ничтожество»,37 - так характеризует Аркадий Долгорукий еще одну сторону своего выбора, как бы солидаризируясь в этом пункте с Ганей Иволгиным. Достоевский неоднократно подчеркивал открывшуюся в новых общественных отношениях возможность посредственности с «миллионом в кармане» первенствовать и обесценивать в них духовно-нравственные аспекты, вообще делать все, что угодно. «Когда можно делать все что угодно? - вопрошает Достоевский в "Зимних заметках о летних впечатлениях". - Когда имеешь миллион. Дает ли свобода каждому по миллиону? Нет. Что такое человек без миллиона? Человек без миллиона есть не тот, который делает все что угодно, а тот, с которым делают все что угодно». ${ }^{38}$ Писатель особо выделил в подготовительных материалах к роману «Подросток» привлекательность для молодого человека перевертывающей и компенсирующей функции этого свойства его «идеи»: «Его, главное, утешает в его системе наживы - беста-

\footnotetext{
36 Достоевский, 1974b, с. 322.

37 Достоевский, 1975, с. 74.

38 Достоевский, 1973b, с. 78.
} 
ланность ее. Именно то, что не нужно гения, ума, образования, а в результате все-таки - первый человек, царь всем и каждому и может отмстить всем обидчикам». ${ }^{39} \mathrm{~B}$ «Подростке» встречается своеобразное рассуждение владельца ссудной кассы Стебелькова о перемене ролей в обновленном обществе:

Я - второй человек. Есть первый человек, и есть второй человек. Первый человек сделает, а второй возьмет. Значит, второй человек выходит первый человек, а первый человек - второй человек [...] Была во Франции революция, и всех казнили. Пришел Наполеон и все взял. Революция - это первый человек, а Наполеон - второй человек. А вышло, что Наполеон стал первый человек, а революция стала второй человек. Так или не так?. 40

Продолжая аналогию Стебелькова, можно сказать, что развитие истории делало Наполеонов - вторыми, а Ротшильдов - первыми людьми в границах темной основы нашей природы, «закона Я». В черновиках Достоевский характеризует «идею Ротшильда» как новое явление и «неожиданное свойство нигилизма» в обществе без оснований и преданий, теряющем религиозные убеждения и нравственные устои. При воцарившемся «беспорядке» (этим словом первоначально обозначалось название романа) «игра на понижение» становилась естественным соблазном для «вторых», стремившихся стать «первыми» с помощью денег, компенсирующих таланты и обесценивающих божественно-царские свойства личности (ср. выстраданное мнение Гани Иволгина: «Деньги тем всего подлее и ненавистнее, что они даже таланты дают»). Общее поветрие хождения «кверху ногами» захватывает и Аркадия Долгорукого, противоречиво и парадоксально сочетаясь в его юношеской душе с жаждой высшего порядка и духовного благообразия. Автор подчеркивает, что Подросток «ищет руководящую нить поведения, добра и зла, чего нет в нашем обществе,

39 Достоевский, 1976, с. 46.

40 Достоевский, 1975, с. 181-182. 
этого жаждет он, ищет чутьем, и в этом цель романа».1 В этих поисках Аркадий сталкивается с самыми разными проявлениями «беспорядка», попадает в водоворот неожиданных и катастрофических происшествий и переносит тяжелые нравственные испытания, в результате которых его «идеи» в «законе Я» теряют над ним свою притягательную власть, но руководящая нить в «законе любви» так и не обретается, хотя на путь познания добра и зла он уже вступил, оставаясь на распутье.

Вопросы, связанные с пирровыми победами человека в истории, с парадоксальной зависимостью между интеллектуальными достижениями и нравственным онемением, не перестали волновать Достоевского в течение всей его жизни. Говоря о грядущих гигантских достижениях науки и техники в деле преобразования и подчинения природы, он спрашивал в «Дневнике писателя»:

Чтобы тогда сталось с людьми? О, конечно, сперва все бы пришли в восторг. Люди обнимали бы друг друга в упоении, они бросились бы изучать открытия (а это взяло бы время); они вдруг почувствовали бы, так сказать, себя осыпанными счастьем, зарытыми в материальных благах; они, может быть, ходили бы или летали по воздуху, пролетали бы чрезвычайные пространства в десять раз скорей, чем теперь по железной дороге; извлекали бы из земли баснословные урожаи, может быть, создали бы химией организмы, и говядины хватило бы по три фунта на человека, как мечтают наши русские социалисты, - словом, ешь, пей и наслаждайся. «Вот, - закричали бы все филантропы, - теперь, когда человек обеспечен, вот теперь только он проявит себя! Нет уж более материальных решений, нет более заедающей "среды", бывшей причиною всех пороков, и теперь человек станет прекрасным и праведным! Нет уж более беспрерывного труда, чтобы как-нибудь прокормиться, и теперь все займутся высшим, глубокими мыслями, всеобщими явлениями. Теперь, теперь только настала высшая жизнь!» [...]

Но вряд ли и на одно поколение людей хватило бы этих восторгов! Люди вдруг увидели бы, что жизни уже более

41 Достоевский, 1976, с. 51. 
нет у них, нет свободы духа, нет воли и личности, что кто-то у них все украл разом; что исчез человеческий лик, и настал скотский образ раба, образ скотины, с тою разницею, что скотина не знает, что она скотина, а человек узнал бы, что он стал скотиной. И загнило бы человечество; люди покрылись бы язвами и стали кусать языки свои в муках, увидя, что жизнь у них взята за хлеб, за «камни, обращенные в хлебы». ${ }^{42}$

Цена такого обращения оказывается настолько великой, что плоды цивилизации и прогресса не только не способствуют совершенствованию «внутреннего человека» (а на это надеются и до сих пор еще продолжат надеяться разнородные «прогрессисты»), но, напротив, понижают его духовную высоту и пленяют потребительскими идолами. Если взглянуть непредвзято и простодушно, вопрошал Достоевский, на то, что мы получили в результате цивилизации? А приобрели мы, отвечал он, «коротенькие идейки и парикмахерское развитие... циничность мысли вследствие ее короткости, ничтожных мелочных форм», окультурились лишь в новых предрассудках, новом платье и новых привычках. Поэтому, считал писатель, необходимо трезво, и, так сказать, заранее определять те или иные стороны намечаемых экономических и социальных задач, постоянно спрашивать себя: «В чем хорошее и что лучшее, вот вопрос... В наше время вопрос: хорошо ли хорошее?»

В клетке сниженных идеалов, невменяемого идолотворчества и потребительской деспотии современного общества, подчеркивает Достоевский, закрепляется гедонистическое жизнеописание и усиливается недружественная разделенность людей: «один раз живем», «хочешь жить, умей вертеться», «рыба ищет где глубже, а человек где лучше», «своя рубашка ближе к телу» и т. п. К тому же новые стандарты жизни маскируют и утончают не лучшие качества человеческой природы. Писатель задает вопрос одного из своих героев:

42 Достоевский, 1981b, с. 33-34. 
И что такое смягчает в нас цивилизация? Цивилизация вырабатывает в человеке только многосторонность ощущений и... решительно ничего больше. А через развитие этой многосторонности человек еще, пожалуй, дойдет до того, что отыщет в крови наслаждение. Ведь это уж и случалось с ним. Замечали ли вы, что самые утонченные кровопроливцы почти сплошь были самые цивилизованные господа, которым все эти Атиллы да Стеньки Разины иной раз в подметки не годились, и если они не так ярко бросаются в глаза, как Атилла и Стенька Разин, так это именно потому, что они слишком часто встречаются, слишком обыкновенны, примелькались. По крайней мере, от цивилизации человек стал если не более кровожаден, то уже, наверно, хуже, гаже кровожаден, чем прежде. Прежде он видел в кровопролитии справедливость и с покойную совестью истреблял кого следовало; теперь же мы хоть и считаем кровопролитие гадостью, а все-таки этой гадостью занимаемся, да еще больше, чем прежде. Что хуже? - сами решите. ${ }^{43}$

Более того, в своих онтологических и антропологических основаниях атеистическая и сциентистская цивилизация, опирающаяся цивилизация на научный технический прогресс, казалась Достоевскому Вавилоновой башней, как бы подводящей апокалиптический итог историческому развитию. В беседе с одним из современников он так говорил о «слепых» проповедниках абстрактных гуманистических ценностей:

Они и не подозревают, что скоро конец всему... всех ихним «прогрессам» и болтовне! Им и не чудится, что ведь антихрист-то уж родился... и идет! - Он произнес это с таким выражением в голосе, и в лице, как будто возвещал мне страшную и великую тайну [...] Идет к нам антихрист! Идет! И конец миру близок, - ближе, чем думают! ${ }^{44}$

Вл. Соловьев по-своему развивает логику Достоевского о ходе исторического процесса. Именно пришествие антихриста и конца мировой истории вообще изобража-

43 Достоевский, 1973с, с. 112.

44 Тимофеева, 1990, с. 180-181. 
ется в повести, которая завершает «Три разговора о войне, прогрессе и конце всемирной истории». Автор ставит «достоевский» вопрос, так мало занимавший прежде его внимание: является ли зло только естественным недостатком или несовершенством, автоматически исчезающим с ростом добра, или оно есть действительная сила, через соблазны владеющая миром, а для борьбы с ней нужна опора в ином порядке бытия? Участники «разговоров» как бы незримо отвечают на этот вопрос, затрагивая самые разные религиозные, духовные, психологические, бытовые, общественные, политические проблемы. Оказывается, что зло реально существует и выражается не в одном отсутствии добра, а в стойком сопротивлении и перевесе низших "рабских» качеств на высшими «царскими» во всех сферах бытия: в индивидуальном зле страсти одолевают высшие стремления души, в общественном зле толпа успешно противостоит усилиям лучших людей, а в физическом зле низшие материальные элементы расторгают прекрасную форму человеческого организма. Все исправители человечества, уповающие на технический прогресс, не способны отсечь сопровождающие его минусы от плюсов и обеспечить перевес высшего над низшим, «закона любви», над «законом Я», а смерть обессмысливает их деятельность.

Соловьев приходит к выводу, что единственной действительной опорой в результативной борьбе добра со злом является реальное воскресение, жизнь во Христе, исцеляющая «темную основу», преображающая душу и превращающая совестливый ум из сомнительного и колеблющегося подсказчика «хорошего поведения» (здесь он как бы повторяет мысль Достоевского о том, что совесть без Христа может заблудиться до своей противоположности) в надежного и твердого проводника самого добра, совершенствования личности, общества, народа, всего человечества.

В логике Соловьева, скрытой и мощной преградой на пути спасительного «внутреннего» просвещения становится поддельное добро, в котором много «гумани- 
стического» и «прогрессивного» блеска, но нет никакой существенной силы. Среди разнообразных проявлений беспомощных общечеловеческих ценностей он выделяет толстовство, называемое им дыромоляйством, вывешиванием фальшивого христианского флага над рационалистической дырой. Ведь христианство без Богочеловека и Евангелия, то есть благая весть без истинного блага, реального воскресения в полноту блаженной жизни, есть такое же пустое место, как просверленная в крестьянской избе обыкновенная дыра. И антихрист в «краткой повести» является выразителем самой главной антропоцентрической подмены в гуманизме Бога человеком, неизбежно абсолютизирующим в отсутствии жизненного Абсолюта существующую несовершенную действительность и свое собственное непросветленное я. Он выступает на мировую арену тогда, когда после освободительной войны с мусульманским миром европейские страны объединяются в соединенные штаты и продолжают наращивать задержанные азиатским нашествием успехи внешней культуры, в то время как главные вопросы о жизни и смерти, об окончательной судьбе мира и человека, осложненные множеством новых исследований в области физиологии и психологии, остаются по-прежнему без разрешения. Наблюдается решительное падение теоретического материализма, уменьшение наивно верующих и возрастание огромного большинства неверующих мыслящих людей. Среди немногих верующих и в то же время мыслящих выделяется по своим сверх-человеческим талантам философ, писатель и общественный деятель, «человек безупречной нравственности и гениальности», написавший книгу «Открытый путь к вселенскому благоденствию и миру» о всеобъемлющем примирении всех противоречий с позиций христианства, но без единого упоминания о Христе. Более того, такая вера в Бога и творимое при этом добро оказываются, как и у великого инквизитора Достоевского, скрытой формой дьявольской зависти и безмерного самолюбия («Я, я, Я, а не Он!.. Не воскрес, 
не воскрес, не воскрес...»), могущественной претензии исправить подвиг Христа и заменить его собой:

Христос пришел раньше меня; я являюсь вторым; но ведь то, что в порядке времени является после, то по существу первое. Я прихожу последним, в конце истории, именно потому, что я современный, окончательный спаситель. Тот Христос - мой предтеча. Его призвание было - предварить и подготовить мое явление [...] Христос, проповедуя и в жизни своей проявляя нравственное добро, был исправителем человечества, я же призван быть благодетелем этого отчасти исправленного, отчасти неисправимого человечества. Я дам всем людям все, что нужно. Христос, как моралист, разделял людей добром и злом, я соединю их благами, которые одинаково нужны и добрым, и злым. Я буду настоящим представителем того Бога, который возводит солнце свое над добрыми и злыми, дождит на праведных и неправедных. Христос принес меч, я принесу мир. Он грозил земле страшным последним судом. Но ведь последним судьею буду я, и суд мой будет не судом правды только, а судом милости. Будет и правда в моем суде, но не правда воздаятельная, а правда распределительная. Я всех различу и каждому дам то, что ему нужно. ${ }^{45}$

Соловьев пишет, что «грядущий человек» с его универсальной программой был почти единогласно выбран в пожизненные президенты Европейских Соединенных Штатов, а затем «во всех языческих странах пораженное и очарованное население провозглашает его верховным богом. ${ }^{46}$ И опять-таки, подобно великому инквизитору, «бог» не может предложить недоделанному и недоисправленному человечеству ничего иного, кроме дьявольских искушений Христа в пустыне, столь подробно проанализированных В. В. Розановым. Материальные блага, равенство всеобщей сытости, полумагические и полунаучные чудеса техники - подобные средства и должны якобы привести людей к вечному миру, а на самом деле приводят к колоссальному понижению их

45 Соловьев, 1988b, с. 741.

46 Соловьев, 1988b, с. 746. 
духовного уровня, к еще большему замутнению различий между высшим и низшим, добром и злом, а соответственно и к непредсказуемым катаклизмам. Здесь Соловьев по-своему солидаризуется с евангельскими предсказаниями о «последних днях», когда люди, проповедуя мир и безопасность, будут под покровом напускного благочестия и поддельного добра самолюбивы, сребролюбивы, горды, надменны, злоречивы, неблагодарны, наглы, напыщенны, более сластолюбивы, нежели боголюбивы.

\section{Ссылки}

БЕРДЯЕВ, Николай. "Русская идея: Основные проблемы русской мысли 19 века и начала 20 века". В кн. Русская идея: Основные проблемы русской мысли 19 века и начала 20 века; Судьба России. Москва: Сварог и К, 1997.

ШЕСТОВ, Лев. "Умозрение и Апокалипсис". В кн. Умозрение и Откровение. Париж: Ymca-Press, 1964.

ФРАНК, Семен. "Русское мировоззрение". В кн.: Духовные основы общества. Москва: Республика, 1992.

ФРАНК, Семен. Реальность и человек. Москва:Республика, 1997.

БАХТИН, Михаил. "К переработке книги о Достоевском". В кн. Эстетика словесного творчества. Москва: Искусство, 1986.

БОЧАРОВ, Сергей. "Об одном разговоре и вокруг него". Новое литературное обозрение, № 2, 1993, с. 70-89.

ДОСТОЕВСКИЙ, Федор. "М. М. Достоевскому. 9 августа". В кн.: Полное собрание сочинений в 30 томах. Т. 28. Кн.1. Ленинград: Наука, 1985.

ДОсТОЕВСКИЙ, Федор. “Бесы. подготовительные материалы". В кн.: Полное собрание сочинений в 30 томах. Т. 11. Ленинград: Наука, 1974а.

СОЛОВЬЕВ, Владимир. “Три речи в память Достоевского” 
В кн.: Собрание сочинений в 2 томах. Т. 2. Москва: Мысль, 1988a.

ДОСТОЕВСКИЙ, Федор. “Господин Щедрин, или раскол в нигилистах". В кн.: Полное собрание сочинений в 30 томах. Т. 20. Ленинград: Наука, 1980.

ДОСТОЕВСКИЙ, Федор. “Дневник писателя. 1881”. В кн.: Полное собрание сочинений в 30 томах. Т. 27. Ленинград: Наука, 1984.

ДОСТОЕВСКИЙ, Федор. “Н. Л. Озмидову. Февраль 1878”. В кн.: Полное собрание сочинений в 30 томах. Т. 30. Кн. 1. Ленинград: Наука, 1988а.

ДОСТОЕВСКИЙ, Федор. “Подросток”. В кн.:Полное собрание сочинений в 30 томах. Т. 13. Ленинград: Наука, 1975.

ДОСТОЕВСКИЙ, Федор. “Н. А. Любимову. 11 июня 1879”. В кн.: Полное собрание сочинений в 30 томах. Т. 30. Кн. 1. Ленинград: Наука, 1988b.

ДОСТОЕВСКИЙ, Федор. “Дневник писателя за 1876 год. Май-октябрь". В кн.: Полное собрание сочинений в 30 томах. Т. 23. Ленинград: Наука, 1981а.

ДОСТОЕВСКИЙ, Федор. “Дневник писателя за 1877 год. Январь-август". В кн.: Полное собрание сочинений в 30 томах. Т. 25. Ленинград: Наука, 1983.

МАРКС, Карл, ЭНГЕЛЬС, Фридрих. "Немецкая идеология". В кн. Полное собрание сочинений в 50 томах. Т. 3. Москва: Государственное издательство политической литературы, 1955.

ДОСТОЕВСКИЙ, Федор. “Преступление и наказание”. В кн.: Полное собрание сочинений в 30 томах. Т. 6. Ленинград: Наука, 1973а.

ДОСТОЕВСКИЙ, Федор. “Записная тетрадь 1875-1876 гг.”. В кн.: Полное собрание сочинений в 30 томах. Т. 24. Ленинград: Наука, 1982.

МАРКС, Карл. “Экономическо-философские рукописи 1844 года". В кн.: К. Маркс и Ф. Энгельс. Из ранних сочинений. M.: Государственное издательство политической литературы, 1956. 
ДОСТОЕВСКИЙ, Федор. “Подросток. Подготовительные материалы". В кн.: Полное собрание сочинений в 30 томах. Т. 16. Ленинград: Наука, 1976.

ДОстОЕВСКИЙ, Федор. “Бесы”. В кн.: Полное собрание сочинений в 30 томах. Т. 10. Ленинград: Наука, 1974b.

ДОСТОЕВСКИЙ, Федор. “Дневник писателя за 1876 год. Январь-апрель". В кн.: Полное собрание сочинений в 30 томах. Т. 22. Ленинград: Наука, 1981b.

ДОСТОЕВСКИЙ, Федор. “Зимние заметки о летних впечатлениях". В кн.: Полное собрание сочинений в 30 томах. Т. 5. Ленинград: Наука, 1973b.

ДОСТОЕВСКИЙ, Федор. “Записки из подполья”. В кн.: Полное собрание сочинений в 30 томах. Т. 5. Ленинград: Наука, 1973с.

ТИМОФЕЕВА, Варвара. "Год работы с знаменитым писателем". В кн.: Достоевский в воспоминаниях современников. Т. 2. Москва:Художественная литература, 1990.

СОЛОВЬЕВ, Владимир. “Три разговора о войне, прогрессе и конце мировой истории". В кн.: Собрание сочинений в 2 томах. Т. 2. Москва: Мысль, 1988b.

Recebido em: 26/12/2020

Aceito em: 11/03/2021

Publicado em abril de 2021 